\title{
Physiological potential of soybean seeds after maturation and submitted to artificial drying ${ }^{1}$
}

\author{
Cesar Pedro Hartmann Filho ${ }^{2 *}$, André Luís Duarte Goneli ${ }^{2}$, Tathiana Elisa \\ Masetto $^{2}$, Elton Aparecido Siqueira Martins ${ }^{2}$, Guilherme Cardoso $\mathrm{Oba}^{2}$
}

\begin{abstract}
This study evaluated the physiological potential of soybean seeds harvested during two seasons, on different maturation stages and subjected to different drying temperatures. The seeds were harvested at the maturations stages R7, R7 + $2, \mathrm{R} 7+3, \mathrm{R} 7+5, \mathrm{R} 7+6, \mathrm{R} 7+7, \mathrm{R} 7+10$ and $\mathrm{R} 7+12$ days $(55,50,45,40,35,30,25$, and 20\% of moisture content). For each maturation stage, seeds were divided into three samples: one sample was used to directly evaluate the physiological potential, and the others were dried at $40{ }^{\circ} \mathrm{C}$ and $50{ }^{\circ} \mathrm{C}$, until reaching the moisture content of $11.5 \%$. The physiological potential was evaluated through germination test, first germination count of germination, accelerated aging, modified cold, electrical conductivity and seedling emergence. The maximum physiological potential of seeds is achieved at the moisture content of $55 \%$, the point that the dry matter is maximum. The seeds became tolerant to artificial drying approximately at the stage $\mathrm{R} 7+$ 7 days (30\% of moisture content). Germination and vigor of the soybean seeds reduce as the drying temperature is increased from $40{ }^{\circ} \mathrm{C}$ to $50{ }^{\circ} \mathrm{C}$, and this effect is enhanced when the seeds show moisture contents above $30 \%$.
\end{abstract}

Index terms: Glycine max L., seed development, germination, seed drying, vigor.

\section{Potencial fisiológico de sementes de soja durante a maturação e submetidas à secagem artificial}

\begin{abstract}
RESUMO - O presente trabalho teve como objetivo avaliar o potencial fisiológico de sementes de soja provenientes de duas épocas de semeaduras, em diferentes estádios de maturidade, submetidas a diferentes temperaturas de secagem. As sementes foram colhidas nos estádios de maturação R7, R7 + 2, R7 + 3, R7 + 5, R7 + 6, R7 + 7, R7 + 10 e R7 + 12 dias $(55,50,45,40$, $35,30,25$ e $20 \%$ de teor de água). Para cada estádio, houve a separação das sementes em três partes, sendo uma diretamente submetida à avaliação do potencial fisiológico, e as outras secas a $40{ }^{\circ} \mathrm{C}$ e $50{ }^{\circ} \mathrm{C}$, até atingirem o teor de água de $11,5 \%$. $\mathrm{O}$ potencial fisiológico foi avaliado pela germinação, primeira contagem, envelhecimento acelerado, frio modificado, condutividade elétrica e emergência. O máximo potencial fisiológico é alcançado com 55\% de teor de água, momento onde o acúmulo de massa seca é máximo. As sementes tornam-se tolerantes à dessecação próximo ao estádio $\mathrm{R} 7+7$ dias $(30 \%$ de teor de água). Germinação e vigor das sementes de soja reduzem com o aumento da temperatura de secagem de $40{ }^{\circ} \mathrm{C}$ para $50{ }^{\circ} \mathrm{C}$, sendo o efeito potencializado quando os teores de água estão acima de $30 \%$.
\end{abstract}

Termos para indexação: Glycine max L., desenvolvimento de sementes, germinação, secagem de sementes, vigor.

\section{Introduction}

Obtaining high quality soybean seeds has historically been one of the major challenges to this commodity production. Besides, from agricultural perspective soybean seeds provide a highly effective strategy transmission of technological genetic information from the mother plant to the next generation. Therefore, in addition to planting soybean crops during atypical seasons, such as the second season crops (Bornhofen et al., 2015), strategies for early and systematized harvest have become more frequent in order to limit the exposure of the seeds to rain and other fluctuations

\footnotetext{
${ }^{1}$ Submitted on $02 / 10 / 2017$. Accepted for publication on 10/05/2017.

${ }^{2}$ Universidade Federal da Grande Dourados, Faculdade de Ciências Agrárias, Caixa Postal 533, $79804-970$ - Dourados, MS, Brasil.

*Corresponding author <cphartmann21@hotmail.com>
} 
in environmental conditions after reaching physiological maturity (Castro et al., 2016).

So, several quiescent dilemmas returned to emerge, such as the optimal harvest time and requirements of the drying process, due to the high moisture contents of harvested materials, that are close to the physiological maturity, have the ability to impair the processes of mechanical harvesting and drying with heated air (Surki et al., 2012).

Soybean seeds typically reach physiological maturity at moisture contents ranging from $50 \%$ to $55 \%$, so, it is common practice to postpone harvesting until after the moisture contents have decreased to $16.5 \%-13 \%$ (Terasawa et al., 2009). However, the maximum physiological potential does not always coincide with tolerance to drying and with a convenient harvest time. In addition, leaving the crop in the field exposes the seeds to adverse conditions that may reduce the performance of the seeds. It is, therefore, necessary to obtain a better understanding of the maturity stage at which the seeds acquire the ability to tolerate drying and the time at which the maximum germination and vigor potential are reached, under different climatic conditions (Carvalho and Novembre, 2012; Zadeh et al., 2014; Donato et al., 2015; Xavier et al., 2015; Castro et al., 2016). Besides, it is important to know the adequate temperature to apply to the seeds as long as the moisture content decreases while seeds remain in the field conditions.

In the present work was evaluated the physiological potential of soybean seeds from two sowing seasons, harvested on different maturation stages and subjected to different drying temperatures.

\section{Materials and Methods}

Soybean seeds were grown under a no-tillage system during two different sowing seasons in 2013-2014. The first season was between October and February (first season crop) and the second season was between January and May (second season crop). The soybean seeds production occurred at Fazenda São Lourenço, located at $22^{\circ} 11^{\prime} 58.06^{\prime \prime} \mathrm{S}, 54^{\circ} 53^{\prime} 24.32^{\prime \prime} \mathrm{W}$ and at 452 meters, in the city of Dourados, MS, Brazil. The rainfall, average daily temperature, and relative humidity data for the experimental periods are shown in Figure 1.

Preparation of the area, in both seasons, consisted of desiccation using Paraquat + Diuron: $400 \mathrm{~g}+200 \mathrm{~g}^{\mathrm{h}} \mathrm{ha}^{-1}$ and

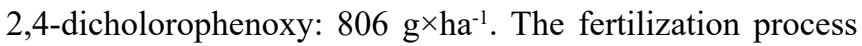
was performed simultaneously with sowing, using $260 \mathrm{~kg} \cdot \mathrm{ha}^{-1}$ of fertilizer 02-20-20 (NPK) which also contained 8\% Ca, 4\% $\mathrm{S}, 0.2 \% \mathrm{Zn}$, and $0.1 \%$ Bo. Seeds from cultivar SYN 1059 RR (V-TOP) were used and treated with insecticides (Fipronil: $12.5 \mathrm{~g}$ for $50 \mathrm{~kg}$ of seeds; Thiamethoxam: $17.5 \mathrm{~g}$ for 50 $\mathrm{kg}$ of seeds) and fungicides (Metalaxyl-M + Fludioxonil: $0.5 \mathrm{~g}+1.25 \mathrm{~g}$ for $50 \mathrm{~kg}$ of seeds). Sowing was performed mechanically, with a spacing of $0.45 \mathrm{~m}$ between the rows at a density of 18 seeds. ${ }^{-1}$, yielding a final density of 355,555 plants.ha ${ }^{-1}$. Each experimental plot consisted of eight rows, each with a length of $10 \mathrm{~m}$, and the growing area of each plot consisted of the six central meters of the four central lines, totaling $10.8 \mathrm{~m}^{2}$.

Manual harvest began at the physiological maturity stage, as determined by Fehr and Caviness (1977), at the stages R7 (one normal pod in the stem with mature pod coloration), R7

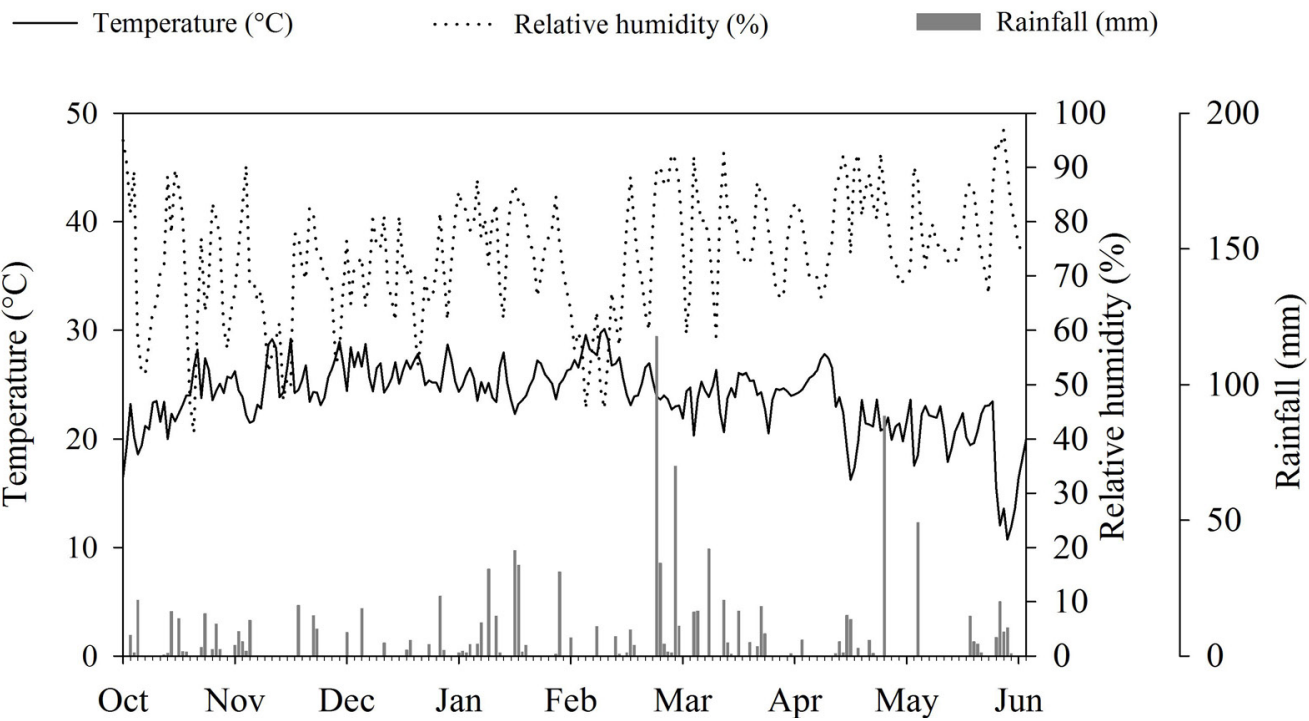

Figure 1. Rainfall index, daily average temperature, and relative humidity during the production of soybean seeds, between October and February (2013-2014), and January and May (2014). 
+ 2 days, $\mathrm{R} 7+3$ days, $\mathrm{R} 7+5$ days, $\mathrm{R} 7+6$ days, $\mathrm{R} 7+7$ days, $\mathrm{R} 7+10$ days and $\mathrm{R} 7+12$ days, corresponding to the seeds with moisture contents of $55,50,45,40,35,30,25$, and $20 \%$ (w.b.), respectively. The moisture contents of the seeds were determined by the oven method at $105^{\circ} \mathrm{C}$, for $24 \mathrm{~h}$, with two subsamples of 200 seeds (about $25 \mathrm{~g}$ ) each (Brasil, 2009). Seeds harvested for each moisture content were divided into three parts: not dried (control), dried at $40^{\circ} \mathrm{C}$, and dried at $50^{\circ} \mathrm{C}$.

The seeds were dried in an experimental fixed-bed dryer, in a drying chamber with a diameter of $0.80 \mathrm{~m}$, and height of $1.0 \mathrm{~m}$. The heating source for the experimental dryer was a set of electrical resistances, with a total power of $12 \mathrm{~kW}$, and an associated centrifugal fan of $0.75 \mathrm{~kW}$ (Ibram, model VSI-160). The temperature was controlled with a universal process controller (Novus, model N1200), together with a Proportional-Integral-Derivative (PID) control. The airflow was $0.2 \mathrm{~m}^{3} \cdot \mathrm{s}^{-1} \cdot \mathrm{m}^{-2}$, selected by using a frequency converter attached to the fan motor.

The seeds were dried at $40{ }^{\circ} \mathrm{C}$ and $50^{\circ} \mathrm{C}$ until they reached a moisture content of $11.5 \%$ (w.b.). The drying process was monitored using the gravimetric method and the gradual mass loss was recorded. While monitoring the drying process, the water reduction rate (WRR) of the soybean seeds at $40^{\circ} \mathrm{C}$ and $50{ }^{\circ} \mathrm{C}$ was determined using Equation 1 (Corrêa et al., 2001), which describes the amount of water that a product loses per unit of dry matter, per unit of time.

$$
\mathrm{WRR}=\frac{\mathrm{Mw}_{0}-\mathrm{Mw}_{\mathrm{i}}}{\operatorname{DM}\left(\mathrm{t}_{\mathrm{i}}-\mathrm{t}_{0}\right)}
$$

where

WRR: water reduction rate, DM: dry matter, in $\mathrm{kg}$ in $\mathrm{kg} \cdot \mathrm{kg}^{-1} \cdot \mathrm{h}^{-1}$

$\mathrm{Mw}_{0}$ : previous total water $\mathrm{t}_{0}:$ previous total drying
time, in $\mathrm{h}$ $\mathrm{Mw}_{\mathrm{i}}$ : current total water $\mathrm{t}_{\mathrm{i}}$ : current total drying time, mass, in $\mathrm{kg}$ in $h$

Several tests were used to evaluate the effect of harvesting seeds with different moisture contents, subjected to different drying temperatures.

Germination and first germination count tests were performed simultaneously, using four subsamples of 50 seeds for each treatment. The seeds were distributed in paper towel rolls moistened with distilled water, in a volume equivalent to two and a half times the mass of the dry paper, and maintained at $25{ }^{\circ} \mathrm{C}$ in a Mangelsdorf germinator. The evaluations were performed on the $5^{\text {th }}$ and $8^{\text {th }}$ days. On the $5^{\text {th }}$ day, the percentage of normal seedlings for the first germination count was calculated; on the $8^{\text {th }}$ day, germination was determined, according to Rules for Seed Testing (Brasil, 2009).

The dry matter test was performed using four subsamples of 50 seeds for each treatment, and the seeds were dried at $105{ }^{\circ} \mathrm{C}$, for $24 \mathrm{~h}$. Subsequently, the mass for each replication was determined using an analytical balance with a resolution of $0.0001 \mathrm{~g}$. To determine the dry matter weight of each seed, each mass was divided by 50 . The results were expressed in $\mathrm{mg}_{\text {.seed }}{ }^{-1}$.

The accelerated aging test was performed according to the method described by Marcos-Filho (1999). Approximately 300 seeds for each treatment were placed in a single uniform layer on a stainless steel screen that was suspended inside a Gerbox plastic box, containing $40 \mathrm{~mL}$ of distilled water at the bottom. The closed boxes were kept in a B.O.D. chamber for $48 \mathrm{~h}$ at a controlled temperature of $41^{\circ} \mathrm{C}$. The moisture content of the seeds was subsequently determined and the germination test was performed (Brasil, 2009). The percentage of normal seedlings was calculated on the $5^{\text {th }}$ day of the test.

The modified cold test was performed according to the method described by Barros et al. (1999), with four subsamples of 50 seeds for each treatment. The seeds were distributed in paper towel rolls moistened with distilled water, in a volume equivalent to three times the mass of the dry paper. These rolls were kept in a B.O.D. chamber for 5 days at $10{ }^{\circ} \mathrm{C}$, and were subsequently transferred to a Mangelsdorf germinator, with a controlled temperature of $25^{\circ} \mathrm{C}$, where they remained for 4 days, after which the percentage of normal seedlings was calculated.

The electrical conductivity test was performed using four subsamples of 50 seeds for each treatment. The seeds were weighed and then placed in $200 \mathrm{~mL}$ glasses to absorb 75 $\mathrm{mL}$ of distilled and deionized water for $24 \mathrm{~h}$, at $25^{\circ} \mathrm{C}$. After this period, a Gehaka digital conductivity meter, model GC 1800 , was used to determine the electrical conductivity of the soaking solution. The results were expressed in $\mu \mathrm{S} . \mathrm{cm}^{-1} \cdot \mathrm{g}^{-1}$ (Vieira and Krzyzanowski, 1999).

The seedling emergence test was performed in trays in a greenhouse, using four subsamples of 100 seeds for each treatment. The number of emerged seedlings was counted daily until the counts were stable. Normal seedlings above the soil surface after 14 days were considered emerged seedlings. The sowing substrate was a 1:1:1 mixture of soil, organic compost and sand.

The experiment was conducted in a factorial scheme of $2 \times 8 \times 3$, consisting of two sowing seasons, eight harvests for the different maturation stages, and three drying temperatures, in a completely randomized design with four replicates. The data were analyzed for the variance and, when significant effects were detected, the data were submitted to polynomial regression analysis. The models were selected according to the magnitude of the coefficient of determination $\left(\mathrm{R}^{2}\right)$, the significance of the regression using the 
F test, and the variable under study.

\section{Results and Discussion}

For all variables analyzed, there were significant interactions between maturation stage and drying treatment. In addition, in the electrical conductivity test, the significant interaction between the sowing season and the drying treatment confirmed that changes in the physiological potential of the seeds were related to these variables (Table 1).
The maximum germination potential $(100 \%)$ occurred when the seeds had the moisture content of 55\% (Figure 2a). However, a reduction in the germination potential followed the moisture content natural decrease, possibly because the field conditions where the seeds were exposed. The seeds with $25 \%$ moisture content, for example, showed $96 \%$ germination. As observed by Holtz and Reis (2013) and Xavier et al. (2015), this fact is usually related to the seeds storage in the field conditions, which ultimately affects not only the seeds physical quality but also physiological attributes such as germination,

Table 1. Variance analysis for germination (G), first germination count (FGC), accelerated aging (AA), modified cold (MCT), electrical conductivity (EC), emergence (EM) and dry matter (DM) tests for soybean seeds, produced in two sowing seasons (SS), harvested with different maturation stage (MS) and subjected to different drying treatments (DT).

\begin{tabular}{|c|c|c|c|c|c|c|c|c|}
\hline \multirow{2}{*}{ Variation sources } & \multirow{2}{*}{$\mathrm{DF}$} & \multicolumn{7}{|c|}{ F calculated } \\
\hline & & G & FGC & $\mathrm{AA}$ & MCT & $\mathrm{EC}$ & EM & $\mathrm{DM}$ \\
\hline $\begin{array}{l}\text { Sowing season } \\
\text { (SS) }\end{array}$ & 1 & $19.3^{* *}$ & $42.9^{* *}$ & $42.4^{* *}$ & $72.5^{* *}$ & $204.6^{* *}$ & $52.3^{* *}$ & $3.5^{\mathrm{ns}}$ \\
\hline $\begin{array}{l}\text { Drying treatment } \\
\text { (DT) }\end{array}$ & 2 & $6151.6^{* *}$ & $6257.3^{* *}$ & $5051.4^{* *}$ & $3811.5^{* *}$ & $37445.7^{* *}$ & $5027.8^{* *}$ & - \\
\hline $\begin{array}{c}\text { Maturation stage } \\
\text { (MS) }\end{array}$ & 6 & $1647.3^{* *}$ & $1424.6^{* *}$ & $1084.6^{* *}$ & $471.9^{* *}$ & $10184.2^{* *}$ & $1226.9^{* *}$ & $135.4^{* *}$ \\
\hline $\mathrm{SS} \times \mathrm{DT}$ & 2 & $2.3^{\mathrm{ns}}$ & $0.5^{\mathrm{ns}}$ & $0.1^{\mathrm{ns}}$ & $1.5^{\mathrm{ns}}$ & $6.1^{* *}$ & $0.5^{\mathrm{ns}}$ & - \\
\hline $\mathrm{SS} \times \mathrm{MS}$ & 6 & $0.1^{\mathrm{ns}}$ & $0.1^{\mathrm{ns}}$ & $0.1^{\mathrm{ns}}$ & $0.1^{\mathrm{ns}}$ & $0.2^{\mathrm{ns}}$ & $0.2^{\mathrm{ns}}$ & $0.02^{\mathrm{ns}}$ \\
\hline $\mathrm{DT} \times \mathrm{MS}$ & 12 & $519.6^{* *}$ & $542.3^{* *}$ & $416.1^{* *}$ & $293.9^{* *}$ & $4211.9^{* *}$ & $461.4^{* *}$ & - \\
\hline $\mathrm{SS} \times \mathrm{DT} \times \mathrm{MS}$ & 12 & $0.1^{\mathrm{ns}}$ & $0.1^{\mathrm{ns}}$ & $0.3^{\text {ns }}$ & $0.1^{\mathrm{ns}}$ & $0.4^{\mathrm{ns}}$ & $0.2^{\mathrm{ns}}$ & - \\
\hline Residual & 126 & - & - & - & - & - & - & - \\
\hline Total corrected & 167 & - & - & - & - & - & - & - \\
\hline $\mathrm{CV} \%$ & - & 2.3 & 2.5 & 3.0 & 3.6 & 1.8 & 2.6 & 2.9 \\
\hline Total average & - & 78.8 & 73.6 & 69.7 & 68.3 & 65.3 & 73.4 & 221.5 \\
\hline
\end{tabular}

DF: degree of freedom; $\mathrm{CV}$ : coefficient of variation; ${ }^{* *}$ significant at $\mathrm{p}<0.01$; ${ }^{\text {ns }}$ not significant.

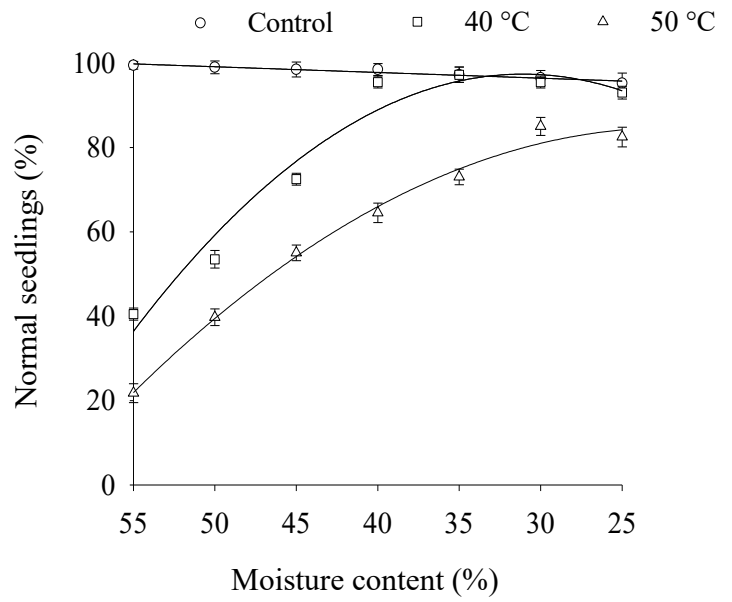

(a)

$\mathrm{G}_{\mathrm{c}}=92.3571+0.1357 \mathrm{MC}\left(\mathrm{R}^{2}=0.9208\right)$

$\mathrm{G}_{40}{ }^{\circ} \mathrm{C}=-5.5000+6.6220 \mathrm{MC}-0.1065 \mathrm{MC}^{2}\left(\mathrm{R}^{2}=0.9461\right)$

$\mathrm{G}_{50}{ }^{\circ} \mathrm{C}=57.0357+2.5232 \mathrm{MC}-0.0575 \mathrm{MC}^{2}\left(\mathrm{R}^{2}=0.9881\right)$

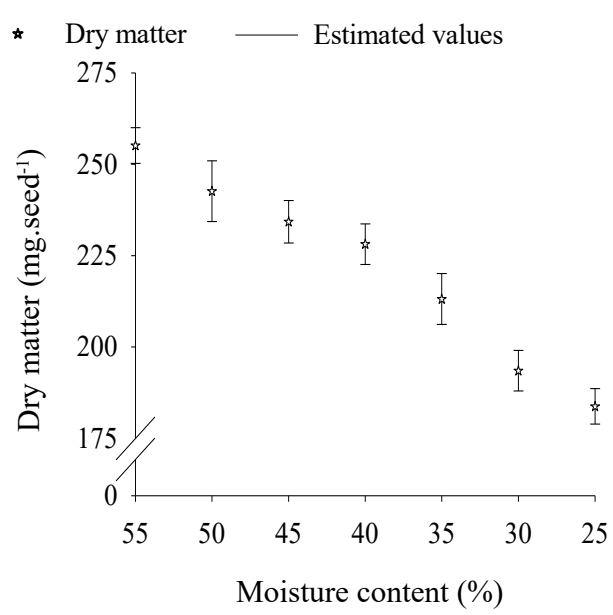

(b)

$\mathrm{DM}=83.1786+4.6774 \mathrm{MC}-0.0287 \mathrm{MC}^{2} \quad\left(\mathrm{R}^{2}=0.9826\right)$

Figure 2. Germination test of the soybean seeds (a), and (b) dry matter of seeds during maturation. 
mainly due to the seeds exposure to fluctuations in temperature and relative humidity accelerating the deterioration.

The relationship observed between germination and seed moisture content corroborated the results observed for the dry matter of seeds during maturation, since the largest dry matter accumulation occurred at the moisture contents of $55 \%$ (253.62 mg.seed $\left.{ }^{-1}\right)$, corresponding to the maximum germination potential of the seeds (Figure 2b). Furthermore, since there was a decrease in dry matter concomitant with the seeds moisture content decrease, suggesting the seeds exposes to uncontrolled environmental conditions in the field affected the seeds quality, most likely because of the deteriorative processes aggravation, which starts when physiological maturity is reached.

The seeds with 55\% moisture content showed the highest germination. When the seeds were dried with air heated to $40^{\circ} \mathrm{C}$ and $50{ }^{\circ} \mathrm{C}$ until reach the moisture contents of $11.5 \%$, germination was reduced to $36 \%$ and $22 \%$, respectively, indicating that the ability to tolerate drying had not yet been completely acquired. However, seeds harvested with the moisture contents of approximately $30 \%$ showed $96 \%$ germination and, when the seeds were dried at $40{ }^{\circ} \mathrm{C}$ and $50{ }^{\circ} \mathrm{C}$, they showed $97 \%$ and $81 \%$ germination, respectively, indicating the ability to withstand after drying was established (Figure 2a). Therefore, desiccation tolerance is acquired during the maturation process indicating the reduction in the seeds moisture content from the physiological maturity, which was remarkable by the gradual acquisition of the seeds germinability. According to Berjak and Pammenter (2013), intracellular physical characteristics become modified with the acquisition of desiccation tolerance, such as changes in cell membranes. Moreover, as suggested by the same authors, deposition of insoluble proteins within vacuoles, thus providing mechanical resilience against cell collapse characterizes the ability of the seeds to lose structural water and, when rehydrated, resume its vital functions, initiating germination and early seedling development.

Drying the seeds at $50{ }^{\circ} \mathrm{C}$ showed a detrimental effect on the soybean seeds. The seeds harvested with moisture contents of $25 \%$ and dried at $40{ }^{\circ} \mathrm{C}$ showed $93 \%$ germination, while the seeds dried at $50{ }^{\circ} \mathrm{C}$ showed $84 \%$ germination, indicating the temperature was a crucial factor leading to reduce the germinability (Figure 2a). As observed by Afrakhteh et al. (2013) for soybean and by Ullmann et al. (2015) for sorghum [Sorghum bicolor (L.) Moench], increasing the air-drying temperature from $40{ }^{\circ} \mathrm{C}$ to $50{ }^{\circ} \mathrm{C}$ adversely affected the germination potential of the seeds. Increasing the speed at which water was removed created a high gradient between the periphery and the interior of the seeds, promoting the formation of cracks in the tegument and microcracks in the cotyledons, which interfered with the early stages of germination, such as the imbibition rate and metabolic reset.

This relationship between increasing drying air temperature and increasing water removal speed was confirmed during the drying process by the water reduction rate. In the present study, the water reduction rate promoted by the drying process increased as the air temperature increased, making the process faster and, at the same time, detrimental to the seeds (Figure 3). Coradi et al. (2016) evaluated the effect of the drying air temperature on the quality of soybeans and found similar results; the coefficient of effective water diffusivity in the product increased as the air temperature increased, thereby increasing the drying speed. Moreover, according to the same authors, although increasing the temperature reduced the duration of the process, the quality of the product was compromised, since physical damage, such as cracks and fissures, was more severe.

In this study, the first germination count showed that the maximum vigor of soybean seeds was reached concomitantly with the maximum seed germination. Seeds with moisture content of $55 \%$ showed $97 \%$ germination in the first germination count, with a subsequent gradual decrease, possibly because of exposure of the seeds to the field environmental conditions lead to the degradation processes (Figure 4). This was also observed and proposed by Nogueira et al. (2014) evaluating the development and physiological quality of cowpea seeds [Vigna unguiculata (L.) Walp.] during the maturation process. The maximum germination and vigor determined by the first germination count test was reached at the time of physiological maturity, when the seeds showed moisture content of approximately $54 \%$, but decreased as the harvest process was delayed. However,

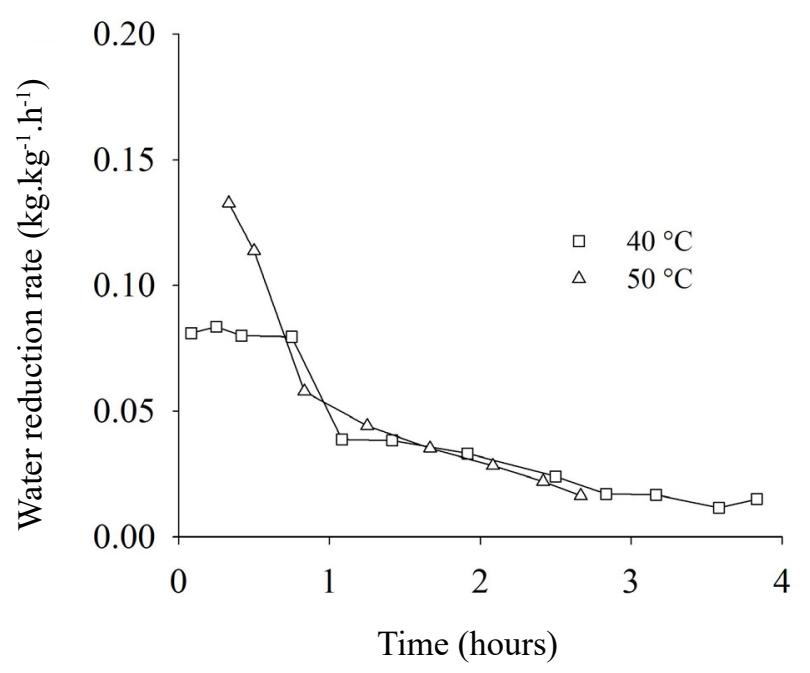

Figure 3. Water reduction rate for the soybean seeds during drying at $40{ }^{\circ} \mathrm{C}$ and $50^{\circ} \mathrm{C}$. 
based on the first germination count test in the present study, the seeds dried at $40{ }^{\circ} \mathrm{C}$ and $50{ }^{\circ} \mathrm{C}$, the maximum vigor was observed for seeds with moisture contents of $30 \%$ and $25 \%$, showing $92 \%$ and $78 \%$ germination, respectively; as soon as desiccation tolerance in soybean seeds occurred later than the seed physiological maturation, a stage at which the seeds still have a high humidity. This suggests the natural drying that occurs in the seeds while they are still physically connected to the main plant is essential for acquiring desiccation tolerance. The vigor of soybean seeds was impaired at the drying temperature of $50{ }^{\circ} \mathrm{C}$, as evidenced by the decrease in the germination speed, with the increase in the drying air temperature (Figure 4).
The maximum vigor of the seeds through the accelerated aging and modified cold tests showed the highest values $(93 \%$ for both tests) for the seeds with $55 \%$ of moisture content (Figure 5). Seed vigor decreased linearly with the permanence of the crop in the field; the harvest time had a direct effect on the maintenance of the physiological quality of the seeds. However, the tolerance to dehydration was gradually acquired. When the soybean seeds attained the moisture content of $30 \%$ and subsequent dried at $40{ }^{\circ} \mathrm{C}$, the maximum values for both the accelerated aging and modified cold tests were 90 and $88 \%$ (Figure 5), indicating that the seeds vigor was more affected when the drying process was performed at moisture contents above $30 \%$, than it was for lower moisture

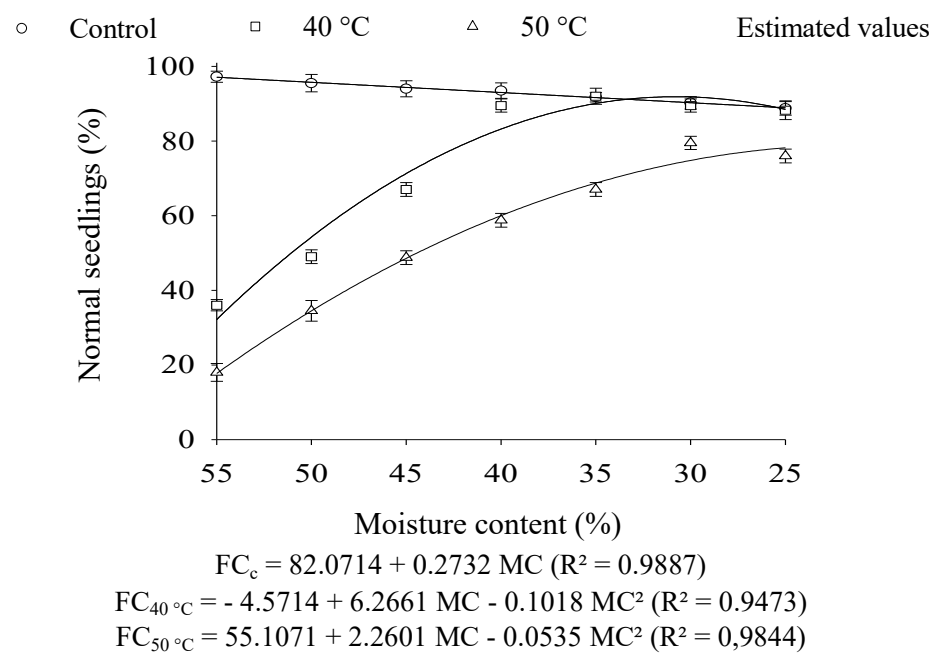

Figure 4. First germination count test of the soybean seeds, related to moisture content and drying temperature.

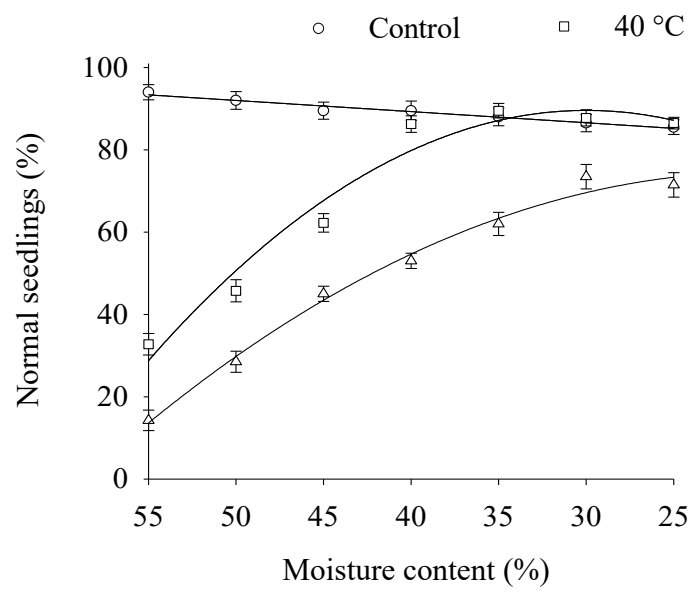

(a)

$\mathrm{AA}_{\mathrm{c}}=78.4286+0.2714 \mathrm{MC}\left(\mathrm{R}^{2}=0.9583\right)$

$\mathrm{AA}_{40}{ }^{\circ} \mathrm{C}=2.2500+5.8250 \mathrm{MC}-0.0971 \mathrm{MC}^{2}\left(\mathrm{R}^{2}=0.9450\right)$

$\mathrm{AA}_{50}{ }^{\circ} \mathrm{C}=54.8571+1.9804 \mathrm{MC}-0.0496 \mathrm{MC}^{2}\left(\mathrm{R}^{2}=0.9859\right)$

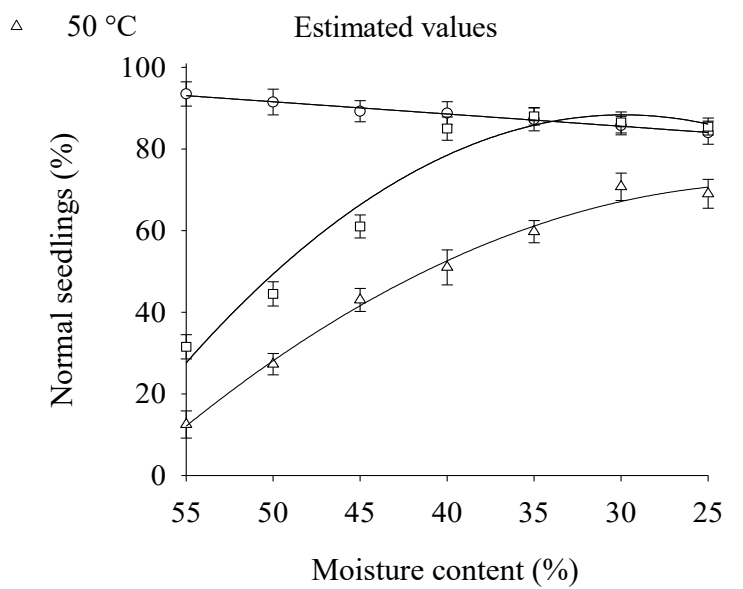

(b)

$\mathrm{MCT}_{\mathrm{c}}=76.5714+0.3000 \mathrm{MC}\left(\mathrm{R}^{2}=0.9819\right)$

$\mathrm{MCT}_{40}{ }^{\circ} \mathrm{C}=2.5714+5.7452 \mathrm{MC}-0.0962 \mathrm{MC}^{2}\left(\mathrm{R}^{2}=0.9456\right)$

$\mathrm{MCT}_{50}{ }^{\circ} \mathrm{C}=50.8571+2.0387 \mathrm{MC}-0.0499 \mathrm{MC}^{2}\left(\mathrm{R}^{2}=0.9877\right)$

Figure 5. Percentage of normal seedlings after the (a) accelerated aging, and (b) modified cold tests of the soybean seeds, related to moisture content and drying temperature. 
contents. As observed by Silva et al. (2007), soybean seed drying with moisture contents above $30 \%$ negatively affected their physiological potential, specially germination and vigor. According to these authors, it is due to the mechanisms responsible for desiccation tolerance were not yet present or active in the seeds, providing rapidly lost of the seeds viability and its ability to germinate and develop vigorous seedlings. According to a series of authors, the desiccation tolerance is acquired due the activation of some proteins that accumulate in the final of maturation stages, such as the LEA proteins, which have the capacity to protect important macromolecules for the germination process, such as enzymes and lipids, according to evolution of the dehydration process, conferring to the seeds a greater cellular stability when they enter on the state of vitreous yet (Dalahaie et al, 2013; Kleinwächter et al., 2014; Righetti et al., 2015; Soares et al., 2015).

At the drying temperature of $50{ }^{\circ} \mathrm{C}$, it was observed that the capacity of the seeds to withstand desiccation only was attained after the physiological maturity (Figure 5). However, this had detrimental effects on the seeds, probably because of faster water removal, confirmed by the WRR (Figure 3). Possibly, the damage at the cellular level was higher at $50{ }^{\circ} \mathrm{C}$, thereby reducing the seeds ability to withstand stressful environmental conditions. Drying soybean seeds with moisture contents above $30 \%$ at temperatures of $50{ }^{\circ} \mathrm{C}$ increased the damage at the cellular level, particularly in the area of the embryonic axis of the soybean seeds (Silva et al., 2007; Afrakhteh et al., 2013), possibly because of its external location in the seed and the relatively thin protective tegument (Pinto et al., 2012). The development of normal seedlings perhaps was compromised by damage in the hypocotyl-radicle axis, which reduced the ability of the seeds to absorb reserves and produce vigorous seedlings (Surki et al.,
2012; Wendt et al., 2014; Pereira et al., 2015).

The electrical conductivity test confirmed the detrimental effect on the soybean seeds physiological quality which was kept in the field after physiological maturity (Figure 6); the low electrical conductivity values $\left(22.90 \mu \mathrm{S} . \mathrm{cm}^{-1} \cdot \mathrm{g}^{-1}\right)$ were observed to the seeds with moisture content of $55 \%$, which gradually increased as the seeds moisture content decrease. Seeds with $25 \%$ moisture content showed electrical conductivity of $39.80 \mu \mathrm{S} . \mathrm{cm}^{-1} \cdot \mathrm{g}^{-1}$, indicating the progress of the deteriorative processes (Figure 6). Diniz et al. (2013), who studied the effect of harvesting time on the physiological potential of soybean seeds, and Jacob Junior et al. (2014), who studied the harvest season for different corn hybrids (Zea mays L.), also found increases in the electrical conductivity of the seed soaking solution, thereby demonstrating the seeds deterioration from the harvest delayed is associated with the decrease in germination and vigor.

According to Castro et al. (2016), several factors, such as fluctuations in temperature and humidity and, depending on the region, rainfall during the harvest season, increased the deteriorative processes in soybean seeds that remained in the field after reaching physiological maturity. These environmental factors can increase the occurrence of pathogenic microorganisms in the seeds, which can also have a negative effect on the physiological potential (Diniz et al., 2013).

The detrimental effects of artificial drying of the soybean seeds were detached in those seeds with moisture contents between $45 \%-55 \%$. For instance, electrical conductivity was very high $\left(143.62 \mu \mathrm{S} . \mathrm{cm}^{-1} . \mathrm{g}^{-1}\right)$ for soybean seeds harvested with moisture contents of $55 \%$ and dried at $40{ }^{\circ} \mathrm{C}$, and $73.33 \mu \mathrm{S} . \mathrm{cm}^{-1} \cdot \mathrm{g}^{-1}$ for seeds harvested with $45 \%$ moisture contents and dried under the same conditions (Figure 6). Therefore, the assessment of the

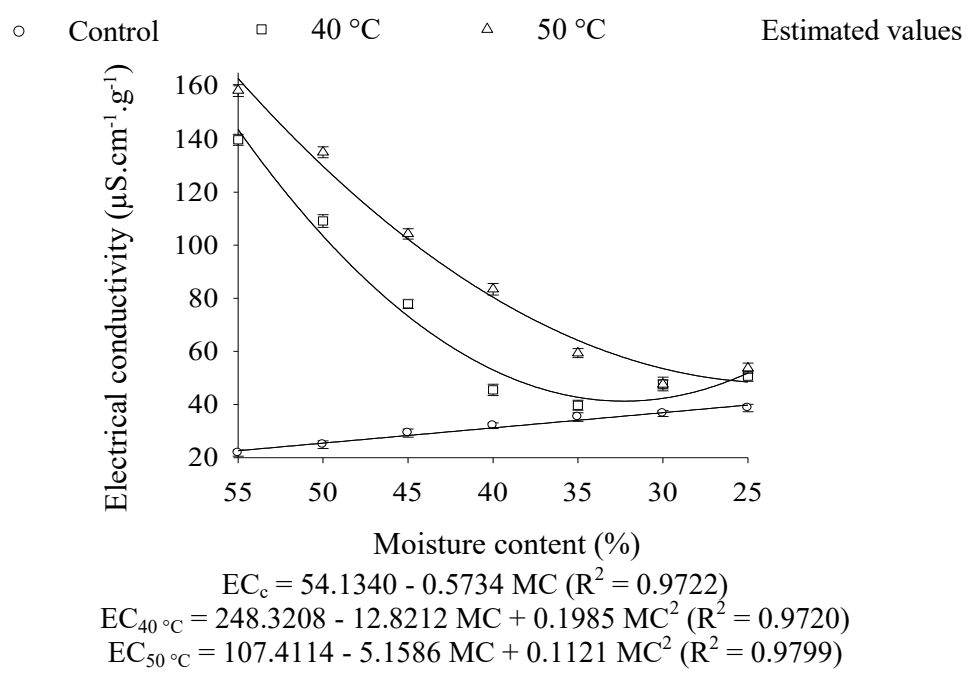

Figure 6. Electrical conductivity of the soybean seed soaking solution, related to moisture content and drying temperature. 
seeds vigor at the two drying temperatures showed that ability to withstand dehydration is gradually acquired during the maturation progress. When the seeds were harvested with moisture content of $32 \%$ following drying at $40{ }^{\circ} \mathrm{C}$, it was observed a minimum value of electrical conductivity (41.31 $\left.\mu \mathrm{S} . \mathrm{cm}^{-1} . \mathrm{g}^{-1}\right)$ (Figure 6), indicating greater desiccation tolerance. However, the seeds with moisture contents slightly lower than $32 \%$ showed increase in the electrical conductivity values, probably because the longer period in the field before the harvest affected the seeds performance.

Drying seeds at the temperature of $50{ }^{\circ} \mathrm{C}$ was detrimental to the physiological quality. The electrical conductivity values at $50{ }^{\circ} \mathrm{C}$ were higher than those at $40{ }^{\circ} \mathrm{C}$, for almost every seed moisture contents (Figure 6). According to Sarath et al. (2016), the electrical conductivity test is suited to identify damages caused through the drying process because the values obtained from this test are usually related with the number of cracks in the seeds and also to the drying temperatures used, due to the air heating increase the electrical conductivity values and the number of cracks. The increase in the drying air temperature compromised the integrity of the cell compartment and facilitates the solutes leakage. Therefore, the cell membranes do not perform efficiently and the selective barrier function decreases at the beginning of the soaking process, which ultimately increases the values of the electrical conductivity (Resende et al., 2012). Thus, this emphasizes the slow drying determined by the low temperature was more suitable to the maintenance of the seeds physiological potential, presumably because sufficient time is given for the induction and operation of protection mechanisms (Barrozo et al., 2014; Zadeh et al., 2014). The results of the electrical conductivity test and the water reduction rates for the two temperatures (Figure 2), as well as for the germination and for the other vigor tests performed, demonstrated that the damages were caused by the increase in the temperature of the drying air.

In the electrical conductivity test, there was a significant interaction between the sowing seasons and the drying treatments (Table 1); the seeds produced in the second season showed higher physiological potential than that one produced in first season, as evidenced by the lower values of electrical conductivity observed in the second harvest (Table 2). This suggests that the seeds grown during the second season were more tolerant to drying with heated air than that one grown during the first season. This fact is possibly related to the lowest temperatures and rainfall occurring during the period of physiological maturity (Figure 1), which may have preserved the quality and physical integrity of seeds, as mentioned by Bornhofen et al. (2015) and Castro et al. (2016).

Emergence results were similar to those obtained for the other vigor tests, confirming that maximum vigor was attained when the seeds had moisture contents of 55\% (95\%

Table 2. Electrical conductivity (in $\mu \mathrm{S} . \mathrm{cm}^{-1} \cdot \mathrm{g}^{-1}$ ) of the soybean seed soaking solution, related to sowing season and drying treatment.

\begin{tabular}{cccc}
\hline \multirow{2}{*}{ Sowing season } & \multicolumn{3}{c}{ Drying treatment } \\
\cline { 2 - 4 } & Control & $40{ }^{\circ} \mathrm{C}$ & $50{ }^{\circ} \mathrm{C}$ \\
\hline First season crop & $32.10 \mathrm{cA}$ & $74.60 \mathrm{bA}$ & $93.10 \mathrm{aA}$ \\
Second season crop & $30.30 \mathrm{cB}$ & $71.20 \mathrm{bB}$ & $90.20 \mathrm{aB}$ \\
\hline
\end{tabular}

Averages followed by the same lower case letter, between drying treatment, and by the same capital letter, between sowing seasons did not differ statistically using the Tukey test $(\mathrm{p} \leq 0.01)$.

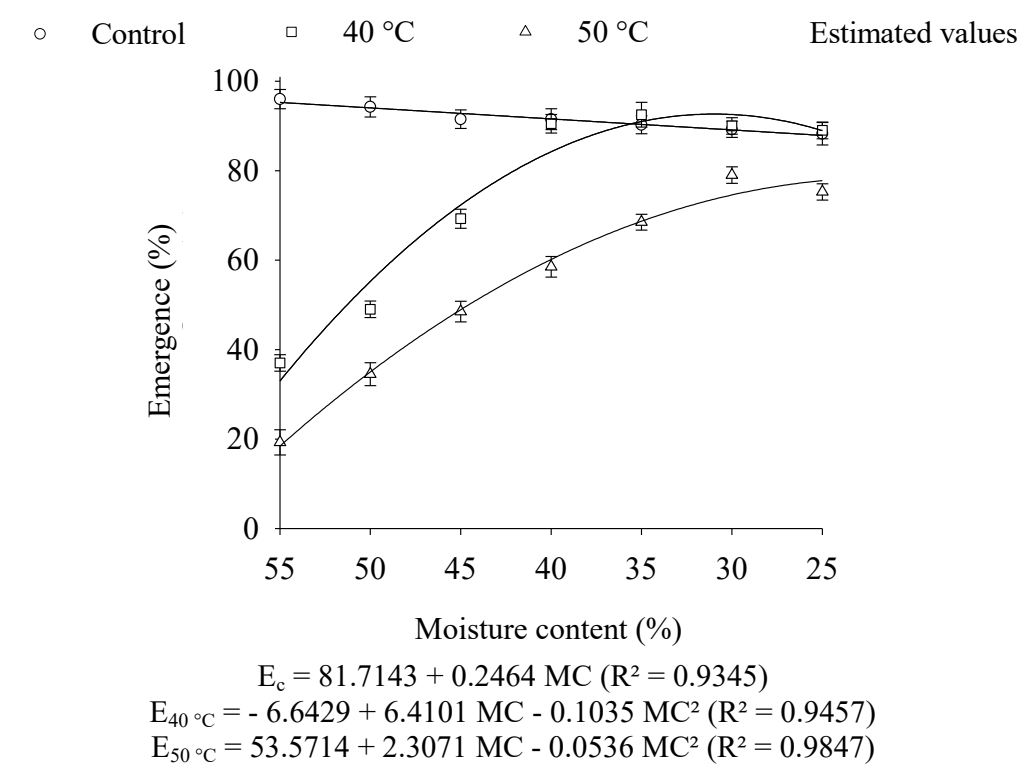

Figure 7. Soybean seed seedling emergence related to moisture content and drying temperature. 
emergence) (Figure 7). A linear reduction in the emergence values was observed during the natural decrease of the moisture content, reducting the physiological potential of the soybean seeds that remained in the field, as also observed by Diniz et al. (2013). This relationship was observed when the seeds were harvested with $25 \%$ moisture content $(88 \%$ emergence; Figure 7).

Donato et al. (2015) observed that the physiological quality of the seeds was influenced according to the maturity stage. Soybean seeds with different physiological quality levels showed differences in the parameters related to the seedling establishment, with the values associated with the emergence decrease as the physiological quality decreased (Diniz et al., 2013; Cantarelli et al., 2015). Therefore, production components, such as the initial and final stand, number of pods per plant, number of seeds per pod, and productivity can be affected (Wendt et al., 2014).

The results found on the emergence test also showed that tolerance to drying increased as long as the seeds maturation proceed and the seeds moisture content decrease (Figure 7). At the drying temperature of $40{ }^{\circ} \mathrm{C}$, emergence reached the maximum $(93 \%)$ when the seeds had moisture content of $31 \%$. However, the quadratic behavior of the regression analysis indicated the delay in the harvesting process could directly affect the physiological quality of the seeds after the maximum point when the values started to decrease. When the seeds were harvested with moisture content of $25 \%$ and dried at $40{ }^{\circ} \mathrm{C}$, the emergence was about $89 \%$. Thus, it was possible to detect a reduction of approximately $0.7 \%$ in the emergence for each $1.0 \%$ decreased in the moisture content, probably due to the deterioration process intensification, and not because of the drying air heat at $40{ }^{\circ} \mathrm{C}$.

The drying air temperature of $50^{\circ} \mathrm{C}$ indicated that increasing this factor directly reduced the seeds quality. This was further confirmed by the lower emergence values at $50{ }^{\circ} \mathrm{C}$ than those at $40{ }^{\circ} \mathrm{C}$. In particular, when the seeds were harvested with $25 \%$ moisture content and dried at $40{ }^{\circ} \mathrm{C}$, the emergence was $89 \%$. At the same moisture content, the maximum emergence of $78 \%$ was observed for the $50^{\circ} \mathrm{C}$. Therefore, although the seeds dried at $40{ }^{\circ} \mathrm{C}$ were exposed to deteriorative processes from the delayed harvest, the capacity to resume their growth based on the emergence of seedlings was much higher than that one observed for the seeds dried at $50{ }^{\circ} \mathrm{C}$ (Figure 7).

According to Surki et al. (2012), drying soybean seeds at temperatures above $40^{\circ} \mathrm{C}$ directly affected their physiological quality. However, this effect was enhanced with seeds moisture contents above $30 \%$. Presumably, drying at high temperatures affects the physical, structural, and metabolic systems of the seeds, thereby disrupting their membranes and the mechanisms related to germination (Costa et al., 2012a,b;
Ullmann et al., 2015). In addition, the detrimental effects of high temperatures can be enhanced when the mechanisms related to withstand severe dehydration are not completely present or effective, depending on the particular stage of maturation, characterized by the seed moisture content. Therefore, tolerance to desiccation in soybean seeds seems to be associated to the seeds maturity stage and to the water reduction rate of the seeds.

\section{Conclusions}

The maximum physiological potential of seeds is achieved at the moisture content of $55 \%$, the point that the dry matter is maximum. The seeds became tolerant to artificial drying approximately at the stage R7 +7 days $(30 \%$ of moisture content). Germination and vigor reduce as the drying temperature is increased from $40^{\circ} \mathrm{C}$ to $50^{\circ} \mathrm{C}$, and this effect is enhanced when the seeds show moisture contents above $30 \%$.

\section{Acknowledgements}

To the Coordenação de Aperfeiçoamento de Pessoal de Nível Superior (Capes) and the Fundação de Apoio ao Desenvolvimento do Ensino, Ciência e Tecnologia do Estado de Mato Grosso do Sul (FUNDCT), due the financial support for research.

\section{References}

AFRAKHTEH, S.; FRAHMANDFAR, E.; HAMIDI, A., RAMANDI, H.D. Evaluation of growth characteristics and seedling vigor in two cultivars of soybean dried under different temperature and fluidized bed dryer. International Journal of Agriculture and Crop Sciences, v.5, n.21, p.2537-2544, 2013. http://ijagcs.com/wp-content/ uploads/2013/09/2537-2544.pdf

BARROS,A.S.R.;DIAS,M.C.L.L.;CICERO, S.M.;KRZYZANOWSKI, F.C. Testes de frio. In: KRZYZANOWSKI, F.C.; VIEIRA, R.D.; FRANCA-NETO, J.B. (Eds.). Vigor de sementes: conceitos e testes. Londrina-PR: ABRATES, 1999. p.5-1 a 5-15.

BARROZO, M.A.S.; MUJUMDAR, A.; FREIRE, J.T. Air-Drying of seeds: A review. Drying Technology: An International Journal, v.32, n. 10, p.1127-1141, 2014. http://www.tandfonline.com/doi/full/10.10 80/07373937.2014.915220

BERJAK, P.; PAMMENTER, N.W. Implications of the lack of desiccation tolerance in recalcitrant seeds. Frontiers in Plant Science, v.4, n.478, p.1-9, 2013. https://www.ncbi.nlm.nih.gov/pmc/ articles/PMC3837223/pdf/fpls-04-00478.pdf

BORNHOFEN, E.; BENIN, G.; GALVAN, D.; FLORES, M.F. Épocas de semeadura e desempenho qualitativo de sementes de soja. Pesquisa Agropecuária Tropical, v.45, n.1, p.46-55, 2015. https:// www.revistas.ufg.br/pat/article/view/29143/18075 
BRASIL. Ministério da Agricultura, Pecuária e Abastecimento. Regras para análise de sementes. Ministério da Agricultura, Pecuária e Abastecimento. Secretaria de Defesa Agropecuária. Brasília: MAPA/ACS, 2009. 395p. http://www.agricultura.gov.br/arq_editor/ file/2946_regras_analise_sementes.pdf

CANTARELLI, L.D.; SCHUCH, L.O.B.; TAVARES, L.C.; RUFINO, C.A. Variabilidade de plantas de soja originadas de sementes de diferentes níveis de qualidade fisiológica. Acta Agronómica, v.64, n.3, p.234-238, 2015. http://www.revistas.unal.edu.co/index.php/ acta_agronomica/article/view/45511/52985

CARVALHO, T.C.; NOVEMBRE, A.D.L.C. Qualidade de sementes de soja colhidas de forma manual e mecânica com diferentes teores de água. Semina: Ciências Agrárias, v.33, n. 1, p.155-166, 2012. http://www.uel.br/revistas/uel/index.php/semagrarias/article/ viewFile/5947/10141

CASTRO, E.M.; OLIVEIRA, J.A.; LIMA, A.E.; SANTOS, H.O.; BARBOSA, J.I.L. Physiological quality of soybean seeds produced under artificial rain in the pre-harvesting period. Journal of Seed Science, v.38, n.1, p.14-21, 2016. http://www.scielo.br/pdf/jss/ v38n1/2317-1537-jss-v38n1154236.pdf

CORADI, P.C.; FERNANDES, C.H.P.; HELMICH, J.C. Adjustment of mathematical models and quality of soybean grains in the drying with high temperatures. Revista Brasileira de Engenharia Agrícola e Ambiental, v.20, n.4, p.385-392, 2016. http://www.scielo.br/pdf/ rbeaa/v20n4/1415-4366-rbeaa-20-04-0385.pdf

CORRÊA,P.C.;MACHADO,P.F.;ANDRADE,E.T.Cinéticadesecagem e qualidade de grãos de milho-pipoca. Ciência e Agrotecnologia, v. 25, n.1, p.134-142, 2001. https://www.agencia.cnptia.embrapa.br/Repositorio/ cineticasecagem_000ffh585q802wx5eo05vmaqk8upbm8a.pdf

COSTA, L.M.; RESENDE, O.; GONÇALVES, D.N.; MARÇAL, K.A.F.; SALES, J.F. Storage of crambe fruit subjected to different drying conditions. African Journal of Agricultural Research, v.7, n.47, p.6274-6280, 2012a. http://www.academicjournals.org/ journal/AJAR/article-full-text-pdf/EA8F89A38755

COSTA, L.M.; RESENDE, O.; GONÇALVES, D.N.; SOUZA, K.A.; SALES, J.F.; DONADON, J.R. The influence of drying on the physiological quality of crambe fruits. Acta Scientiarum. Agronomy, v.34, n.2, p.213-218, 2012b. http://www.scielo.br/pdf/ asagr/v34n2/14.pdf

DALAHAIE, J.; HUNDERTMARK, M.; BOVE, J.; LEPRINCE, O.; ROGNIAUX, H.; BUITINK, J. LEA polypeptide profiling of recalcitrant and orthodox legume seeds reveals ABI3-regulated LEA protein abundance linked to desiccation tolerance. Journal Experimental Botany, v.64, n.14, p.4559-4573, 2013. https://www. ncbi.nlm.nih.gov/pmc/articles/PMC3808335/pdf/ert274.pdf

DINIZ, F.O.; REIS, M.S.; DIAS, L.A.S.; ARAÚJO, E.F.; SEDIYAMA, T.; SEDIYAMA, C.A. Physiological quality of soybean seeds of cultivars submitted to harvesting delay and its association with seedling emergence in the field. Journal of Seed Science, v.35, n.2, p.147-152, 2013. http://www.scielo.br/pdf/jss/v35n2/02.pdf
DONATO, L.M.S.; RABELO, M.M.; DAVID, A.M.S.S.; ROCHA, A.F.; ROCHA, A.S.; BORGES, G.A. Qualidade fisiológica de sementes de melão em função do estádio de maturação dos frutos. Comunicata Scientiae, v.6, n.1, p.49-56, 2015. https:// comunicatascientiae.com.br/comunicata/article/view/544/302

FEHR, W.R.; CAVINESS, C.E. Stages of soybean development. Special Report, n.80, Ames: Iowa State University of Science and Technology, 1977. 11p.

HOLTZ, V.; REIS, E.F. Perdas na colheita mecanizada de soja: uma análise quantitativa e qualitativa. Revista Ceres, v.60, n.3, p.347353, 2013. http://www.scielo.br/pdf/rceres/v60n3/07.pdf

JACOB JUNIOR, E.A.; MERTZ, L.M.; HENNING, F.A.; PESKE, S.T.; VILLELA, F.A.; LABBÉ, L.M.B. Ideal seeds harvest moment of different maize hybrids. Ciência Rural, v.44, n.2, p.253-260, 2014. http://www.scielo.br/pdf/cr/v44n2/a6014cr6031.pdf

KLEINWÄCHTER, M.; RADWAN, A.; HARA, M.; SELMAR, D. Dehydrin expression in seeds: an issue of maturation drying. Frontiers in Plant Science, v.5, n.402, p.1-3, 2014. https://www.ncbi.nlm.nih.gov/ pmc/articles/PMC4145252/pdf/fpls-05-00402.pdf

MARCOS-FILHO, J. Teste de envelhecimento acelerado. In: KRZYZANOWSKI, F.C.; VIEIRA, R.D.; FRANÇA-NETO, J.B. (Eds.). Vigor de sementes: conceitos e testes. Londrina-PR: ABRATES, 1999. p.3-1 a 3-24.

NOGUEIRA, N.W.; FREITAS, R.M.O; TORRES, S.B.; LEAL, C.C.P. Physiological maturation of cowpea seeds. Journal of Seed Science, v.36, n.3, p.312-317, 2014. http://www.scielo.br/pdf/jss/ v36n3/06.pdf

PEREIRA, W.A.; PEREIRA, S.M.A.; DIAS, D.C.F.S. Dynamics of reserves of soybean seeds during the development of seedlings of different commercial cultivars. Journal of Seed Science, v.37, n.1, p.63-69, 2015. http://www.scielo.br/pdf/jss/v37n1/2317-1537jss-37-01-00063.pdf

PINTO, T.L.F.; VAZ MONDO, V.H.; GOMES JÚNIOR, F.G.; CICERO, S.M. Análise de imagens na avaliação de danos mecânicos em sementes de soja. Pesquisa Agropecuária Tropical, v.42, n.3, p.310-316, 2012. http://www.scielo.br/pdf/pat/v42n3/a09v42n3.pdf

RESENDE, O.; ALMEIDA, D.P.; COSTA, L.M.; MENDES, U.C.; SALES, J.F. Adzuki beans (Vigna angularis) seed quality under several drying conditions. Ciência e Tecnologia de Alimentos, v.32, n.1, p.151155, 2012. http://www.scielo.br/pdf/cta/v32n1/aop_cta_5007.pdf

RIGHETTI, K.; VU, J.L.; PELLETIER, S.; VU, B.L.; GLAAB, E.; LALANNE, D.; PASHA, A.; PATEL, R.V.; PROVART, N.J.; VERDIER, J.; LEPRINCE, O.; BUITINK, J.. Inference of longevityrelated genes from a robust coexpression network of seed maturation identifies regulators linking seed storability to biotic defense-related pathways. Plant Cell, v.27, n.10, p.2692-2708, 2015. https://www. ncbi.nlm.nih.gov/pubmed/26410298

SILVA, P.A.; DINIZ, K.A.; OLIVEIRA, J.A.; VON PINHO, E.V.R. Análise fisiológica e ultra-estrutural durante o desenvolvimento e a secagem de sementes de soja. Revista Brasileira de Sementes, v.29, n.2, p.15-22, 2007. http://www.scielo.br/pdf/rbs/v29n2/v29n2a03.pdf 
SOARES, G.C.M.; DIAS, D.C.S.F.; JOSÉ, M.R.; FARIA, J.M.R.; BORGES, E.E.L. Physiological and biochemical changes during the loss of desiccation tolerance in germinating Adenanthera pavonina L. seeds. Anais da Academia Brasileira de Ciências, v.87, n.4, p.2001-2011, 2015. http://www.scielo.br/pdf/aabc/v87n4/0001-3765aabc-201520140195.pdf

SURKI, A.A.; SHARIFZADEH, F.; AFSHARI, R.T. Effect of drying conditions and harvest time on soybean seed viability and deterioration under different storage temperature. African Journal of Agricultural Research, v.7, n.36, p.5118-5127, 2012. http://www.academicjournals. org/article/article1380883260_Surki\%20et\%20al.pdf

TERASAWA, J.M.; PANOBIANCO, M.; POSSAMAI, E.; KOEHLER, H.S. Antecipação da colheita na qualidade fisiológica de sementes de soja. Bragantia, v.68, n, 3, p.765-773, 2009. http://www.scielo.br/pdf/ brag/v68n3/a25v68n3.pdf

ULLMANN, R.; RESENDE, O.; CHAVES, T.H.; OLIVEIRA, D.E.C.; COSTA, L.M. Qualidade fisiológica das sementes de sorgo sacarino submetidas à secagem em diferentes condições de ar. Revista Brasileira de Engenharia Agrícola e Ambiental, v.19, n.1, p.64-69, 2015. http://www.agriambi.com.br/revista/v19n01/v19n01a11.pdf

VIEIRA, R.D.; KRZYZANOWSKI, F.C. Teste de condutividade elétrica. In: KRZYZANOWSKI, F.C.; VIEIRA, R.D.; FRANÇANETO, J.B. (Eds.). Vigor de sementes: conceitos e testes. Londrina, ABRATES, 1999. p.4-1 a 4-26.
WENDT, L.; GOMES JUNIOR, F.G.; ZORATO, M.F.; MOREIRA, G.C. Avaliação do potencial fisiológico de sementes de soja por meio de imagens. Pesquisa Agropecuária Tropical, v.44, n.3, p.280-286, 2014. http://www.scielo.br/pdf/pat/v44n3/a11v44n3.pdf

XAVIER, T.S.; DARONCH, D.J.; PELUZIO, J.M.; AFFÉRRI, F.S.; CARVALHO, E.V.; SANTOS, W.F. Época de colheita na qualidade de sementes de genótipos de soja. Comunicata Scientiae, v.6, n.2, p.241-245, 2015. https://www.comunicatascientiae.com.br/ comunicata/article/download/752/323

ZADEH, H.M.I.; MAHMOODI, T.M.; KHALILIAQDAM, N. Effect of different harvesting times on the seed quality of barley cultivars. Journal of Biological Sciences, v.14, n.8, p.532-536, 2014. http://docsdrive.com/pdfs/ansinet/jbs/2014/532-536.pdf 